\title{
Membangun Literasi Digital Bagi Warga Desa Hurung, Kecamatan Banama Tingang, Kabupaten Pulang Pisau
}

\author{
Enny Dwi Oktaviyani*, Ariesta Lestari, Licantik \\ *Universitas Palangka Raya \\ *Email : enny.obrien@gmail.com
}

\begin{abstract}
Digital literacy is defined as the ability to understand and use information in various forms from various sources accessed through computer devices. Digital literacy will create a society with a critical-creative mindset and views. Provocative issues will not easily consume it, become victims of hoax information, or victims of digitalbased fraud. Residents of Hurung Village, Banama Tingang District, Pulang Pisau Regency are partners in this community service activity who are active users of digital technology via mobile phones to access the internet and interact with other people. However, in digital technology, partners have not been able to distinguish true or false information and forward information obtained from social media or unclear sources. Likewise, in the search for information, still using sources or references that are not valid. So that the information obtained cannot be justified. In this service activity, the service team created digital media using a village profile website to support digital literacy for Hurung village. The activity was carried out in three stages, namely material presentation, mentoring, and training on the use of village profile websites. With this activity, it is hoped that it can be helpful to add insight, knowledge and build Hurung village to become a pioneer village of digital literacy
\end{abstract}

Keywords: Digital Literacy, Hurung Village, Website

\section{How to Cite:}

Oktaviyani, E. D., Lestari, A., \& Licantik, (2021). Membangun literasi digital bagi warga Desa Hurung, Kecamatan Banama Tingang, Kabupaten Pulang Pisau. Jurnal Nasional Pengabdian Masyarakat, 2(2), 49-59. DOI : https://doi.org/10.47747/jnpm.v2i2.386

\section{Pendahuluan}

Indonesia merupakan salah satu negara dengan jumlah pengguna internet terbesar di dunia. Menurut hasil riset yang dilakukan oleh Asosiasi Penyelenggara Jasa Internet Indonesia (APJII) bersama dengan Pusat Kajian Komunikasi (Puskakom) Universitas Indonesia, total jumlah pengguna Internet di Indonesia per awal 2015 adalah 88,1 juta orang. Akan tetapi, sesuai dengan riset yang dilansir oleh wearesocial.sg pada tahun 2017 tercatat ada sebanyak 132 juta pengguna internet di Indonesia dan angka ini tumbuh sebanyak 51 persen dalam kurun waktu satu tahun (Nasrullah et al., 2017).

Literasi digital diartikan sebagai kemampuan untuk memahami dan menggunakan informasi dalam berbagai bentuk dari berbagai sumber yang sangat luas yang diakses melalui piranti komputer (Gilster, 1997). Literasi digital sama pentingnya dengan membaca, menulis, berhitung, dan disiplin ilmu lainnya. Generasi yang tumbuh di era teknologi digital saat ini 
mempunyai pola pikir yang berbeda dengan generasi sebelumnya. Masyarakat harus dapat bertanggung jawab dan bijaksana dalam menggunkana teknologi untuk berinteraksi dengan lingkungan sekitarnya. Teknologi digital memungkinkan setiap orang dapat berinteraksi dan berkomunikasi dengan keluarga, teman, rekan kerja dan siapapun dalam kehidupan seharihari. Masyarakat saat ini perlu menguasai kompetensi digital agar tidak tersisih dalam persaingan memperoleh pekerjaan dan interaksi social. Membangun budaya literasi digital perlu melibatkan peran aktif masyarakat secara bersama-sama. Keberhasilan membangun literasi digital merupakan salah satu indikator pencapaian dalam bidang pendidikan dan kebudayaan (Nasrullah et al., 2017).

Di era teknologi serba digital ini segala informasi apapun dapat diakses dengan mudah, namun tidak semua informasi yang disajikan semuanya benar dan positif. Banyak konten berbau berita bohong, ujaran kebencian, dan radikalisme, bahkan praktik-praktik penipuan yang dapat merusak generasi muda saat ini. Karena itu penting bagi masyarakat untuk menyaring informasi-informasi negative. Literasi digital akan menciptakan tatanan masyarakat dengan pola pikir dan pandangan yang kritis-kreatif. Mereka tidak akan mudah termakan oleh isu yang provokatif, menjadi korban informasi hoaks, atau korban penipuan yang berbasis digital. Pada era digital ini juga pelaksanaan pembangunan pedesaan sangat membutuhkan sistem komunikasi yang mengintegrasikan komunikasi interpersonal, media massa dan media hibrida (Bungai et al., 2020)

Desa Hurung adalah salah satu desa yang berada di Kabupaten Banama Tingang, Provinsi Kalimantan Tengah dengan jumlah penduduk 311 jiwa (BPS Pulang Pisau, 2014). Desa Hurung mempunyai sinyal seluler dan listrik yang cukup kuat sehingga memudahkan warga untuk mengakses internet. Warga desa cukup aktif menggunakan teknologi digital melalui telepon genggam untuk berinteraksi dengan orang lain dan mengakses internet. Namun dalam pemanfaatan teknologi digital tersebut, mereka belum dapat membedakan informasiinformasi yang benar atau yg palsu (hoaks) dan meneruskan informasi-informasi yang didapat dari social media atau sumber yang tidak jelas. Demikian juga dalam pencarian informasi, masih menggunakan sumber-sumber atau referensi yang tidak valid. Sehingga informasi yang didapat tidak dapat dapat dipertanggungjawabkan kebenarannya.

\section{Solusi Masalah}

Berdasarkan permasalahan diatas, maka solusi yang diperlukan adalah mengadakan kegiatan Pengabdian Kepada Masyarakat yang terdiri dari pemaparan materi, pendampingan dan pelatihan mengenai literasi digital bagi warga desa Hurung. Pembangunan desa saat ini tidak lepas dari dukungan teknologi informasi, hampir disetiap desa membutuhkan teknologi informasi guna meningkatkan layanan kepada masyarakat (Jimi, 2019). Kegiatan ini diharapkan dapat membantu membuka wawasan dan pengetahuan bagi warga untuk membangun literasi digital dan menggunakan teknologi digital secara tepat. Tabel 1 menunjukkan uraian solusi yang ditawarkan untuk menyelesaikan permasalahan mitra. 
Vol. 2, No. 2, Juli-Desember 2021

Tabel 1 . Solusi permasalahan kelompok mitra

\begin{tabular}{|c|c|}
\hline Permasalahan & Solusi \\
\hline $\begin{array}{l}\text { Kurangnya wawasan dan informasi } \\
\text { mitra mengenai literasi digital dan } \\
\text { manfaat literasi digital }\end{array}$ & $\begin{array}{l}\text { Memberikan pemahaman dan } \\
\text { penjelasan mengenai literasi digital, } \\
\text { pengertian literasi digital, pentingnya } \\
\text { mengetahui literasi digital, manfaat } \\
\text { literasi digital, jenis kegiatan yang } \\
\text { mencakup literasi digital, serta hal-hal } \\
\text { yang perlu diperhatikan dalam } \\
\text { memanfaatkan literasi digital dan } \\
\text { internet sehat }\end{array}$ \\
\hline
\end{tabular}

Kurangnya pemahaman mitra dalam memanfaatkan teknologi digital sebagai sumber informasi

pendampingan dan mempraktekkan secara langsung bagaimana pemilihan sumber-sumber literasi digital yang tepat, menyaring informasi-informasi yang valid, dan menggunakan internet secara sehat

Desa Hurung belum mempunyai media digital untuk mengenalkan dan mempromosikan daerahnya
Membuat suatu website profil sebagai media digital bagi desa Hurung sebagai bentuk dukungan tim pengabdian untuk membangun literasi digital bagi desa Hurung

\section{Metode Pelaksanaan}

Kegiatan Pengabdian Kepada Masyarakat dilaksanakan di Balai Desa Hurung, Kecamatan Banama Tingang Kabupaten Pulang Pisau dengan pesertanya adalah warga desa. Metode pelaksanaan kegiatan di tunjukkan pada gambar 1. Jarak dari Fakultas Teknik Universitas Palangka Raya ke lokasi kegiatan adalah 71 km dengan jarak tempuh sekitar 1 jam 36 menit. Gambar 2 menunjukkan peta jalan dengan titik awal diambil dari Fakultas Teknik Universitas Palangka Raya yang dilihat menggunakan Google Map. Sasaran mitra pada kegiatan ini adalah warga Desa Hurung. 
Vol. 2, No. 2, Juli-Desember 2021

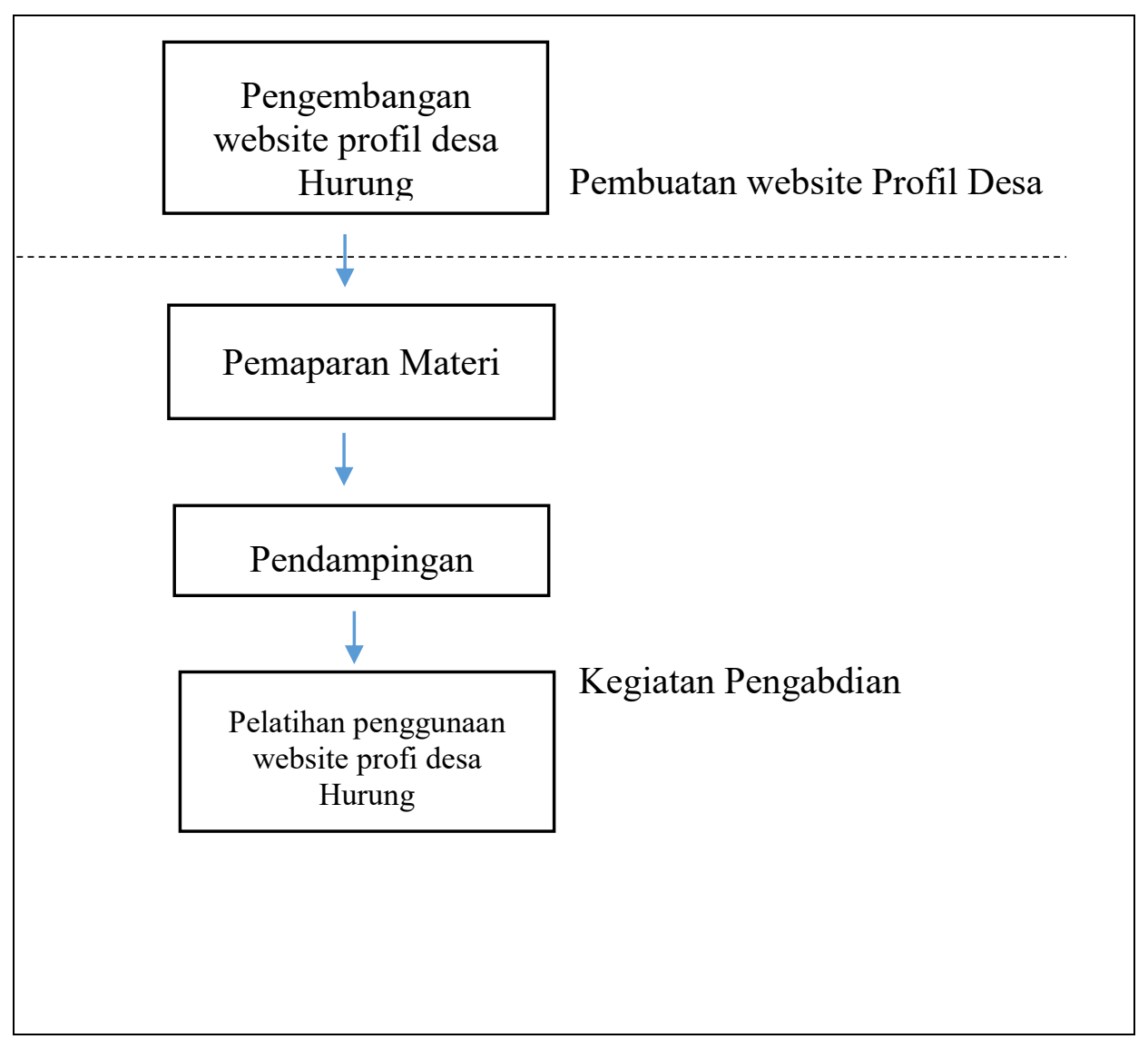

Gambar 1. Metode Pelaksanaan Kegiatan

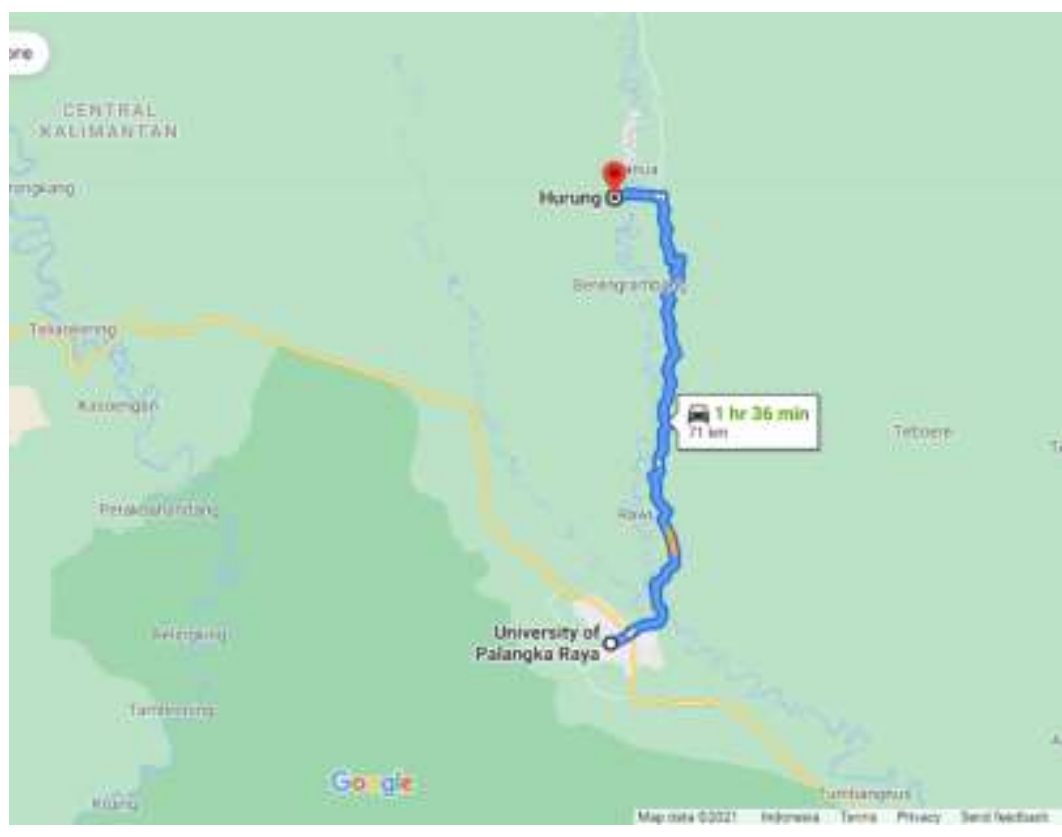

Gambar 2. Peta Jalan Ke Lokasi Mitra 
Kegiatan ini dilaksanakan dalam 3 tahap, yaitu pemaparan materi, pendampingan materi, pelatihan penggunaan website profil desa. Setelah melakukan tahapan kegiatan pengabdian ada beberapa indikator keberhasilan kegiatan ini. Indikator keberhasilan tersebut dapat dilihat pada Tabel 2

Tabel 2. Indikator Keberhasilan Kegiatan

\begin{tabular}{l} 
Tahap Kegiatan \\
\hline 1. Memberikan pemahaman dan penjelasan \\
mengenai literasi digital, pengertian literasi \\
digital, pentingnya mengetahui literasi \\
digital, manfaat literasi digital, jenis \\
kegiatan yang mencakup literasi digital, \\
serta hal-hal yang perlu diperhatikan dalam \\
memanfaatkan literasi digital dan internet \\
sehat
\end{tabular}

2. Pendampingan dan mempraktekkan secara langsung bagaimana pemilihan sumbersumber literasi digital yang tepat, menyaring informasi-informasi yang valid, dan menggunakan internet secara sehat

3. Pelatihan penggunaan website profil
Indikator Keberhasilan

1. Memahami pentingnya literasi digital dengan indicator capaian peserta dapat menjawab pertanyaan-pertanyaan dalam bentuk games yang diberikan pemateri

2. Peserta memahami manfaat literasi digital dalam kehidupan sehari-hari.

1. Peserta dapat melakukan pencarian informasi, menyeleksi dan memilih sumber atau referensi yang terpercaya

2. Peserta dapat menggunakan internet sebagai penyedia informasi secara tepat

3. Peserta dapat membedakan informasi hoaks dan tidak

Peserta dapat menggunakan website profil dengan baik

Evaluasi yang dilakukan untuk mengukur tercapainya indikator keberhasilan dengan menggunakan evaluasi awal, evaluasi proses, dan evaluasi akhir.

1. Evaluasi awal

Evaluasi awal dilakukan pada tahap awal kegiatan pengabdian dengan memberikan beberapa pertanyaan lisan yang terkait dengan materi yang akan disampaikan. Kemudian akan dilakukan pengamatan apakah peserta dapat menjawab pertanyaanpertanyaan tersebut

2. Evaluasi proses

Evaluasi proses dilakukan setelah evaluasi awal dengan melakukan pengamatan untuk mengetahui apakah kegiatan yang dilaksanakan sesuai dengan tujuan kegiatan pengabdian dan mengetahui suasana pada saat kegiatan berlangsung. Pengamatan yang dilakukan berupa banyaknya pertanyaan yang diberikan oleh peserta dan respon yang diberikan oleh peserta terhadap materi yang disampaikan

3. Evaluasi akhir

Evaluasi akhir dilakukan untuk mengetahui pemahaman peserta setelah kegiatan pengabdian selesai dilakukan dengan memberikan pertanyaan yang sama seperti pada evaluasi awal. Jika peserta dapat menjawab dengan lebih baik, dan mempraktekkan apa yang telah disampaikan dengan baik maka kegiatan dianggap telah berhasil dilaksanakan. 


\section{Hasil Pelaksanaan dan Diskusi}

\subsection{Website Desa Hurung}

Website desa dapat digunakan diantaranya untuk media pelayanan public dan manajemen informasi desa (Https://www.puskomedia.id, n.d.)Tahap pertama yang dilakukan pada kegiatan pengabdian ini adalah pembuatan Website Desa Hurung. Website Desa Hurung dibuat dengan menggunakan Bahasa pemrograman PHP dan database MySQL. Website ini dapat digunakan oleh Aparatur Desa untuk memberikan informasi-informasi terkait dengan Desa Hurung, dan digunakan oleh warga desa Hurung untuk memperoleh informasi terkait dengan Desa Hurung. Menu-menu yang terdapat dalam website ini adalah :

1. Menu Beranda

Menu beranda merupakan halaman awal dari website. Menu beranda ditunjukkan pada gambar 3.

2. Menu Berita

Menu berita berisi berita-berita terkait dengan Desa Hurung. Menu berita ditunjukkan pada Gambar 4.

3. Menu Profil Desa

Menu profil desa berisi tentang visi misi, struktur organisasi, dan profil Kepala Desa.

4. Menu Agenda

Menu agenda berisi agenda atau jadwak kegiatan yang akan dilaksanakan.

5. Menu Galery

Menu gallery berisi foto-foto kegiatan yang dilaksanakan di Desa Hurung.

6. Menu Data Desa

Menu data desa berisi data desa yang terkait dengan data penduduk berdasarkan mata pencaharian, jenis kelamin, Pendidikan, agama, dan umur/usia. Menu data desa ditunjukkan pada Gambar 5

7. Menu Kontak

Pada menu kontak, pengunjung menghubungi pihak Desa Hurung dengan mengisikan komentar.

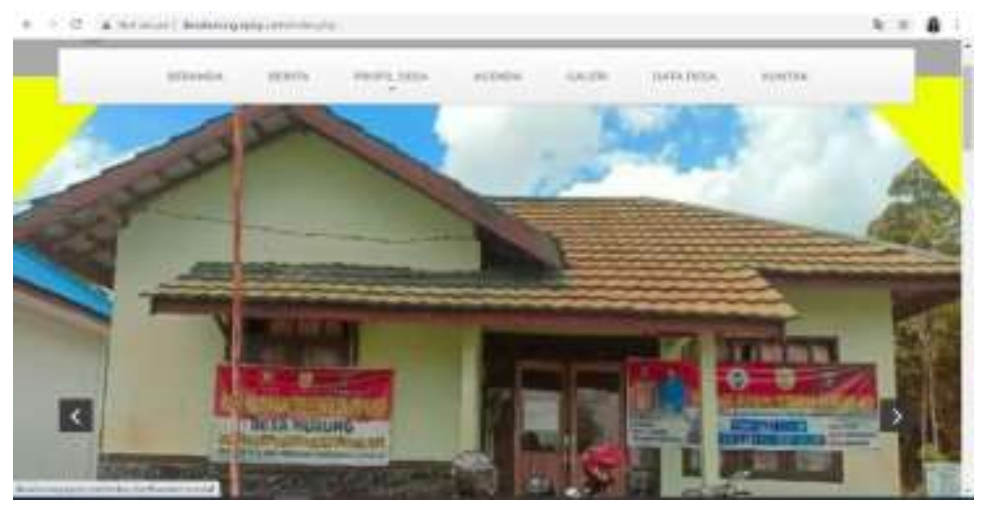

Gambar 3. Menu Beranda 


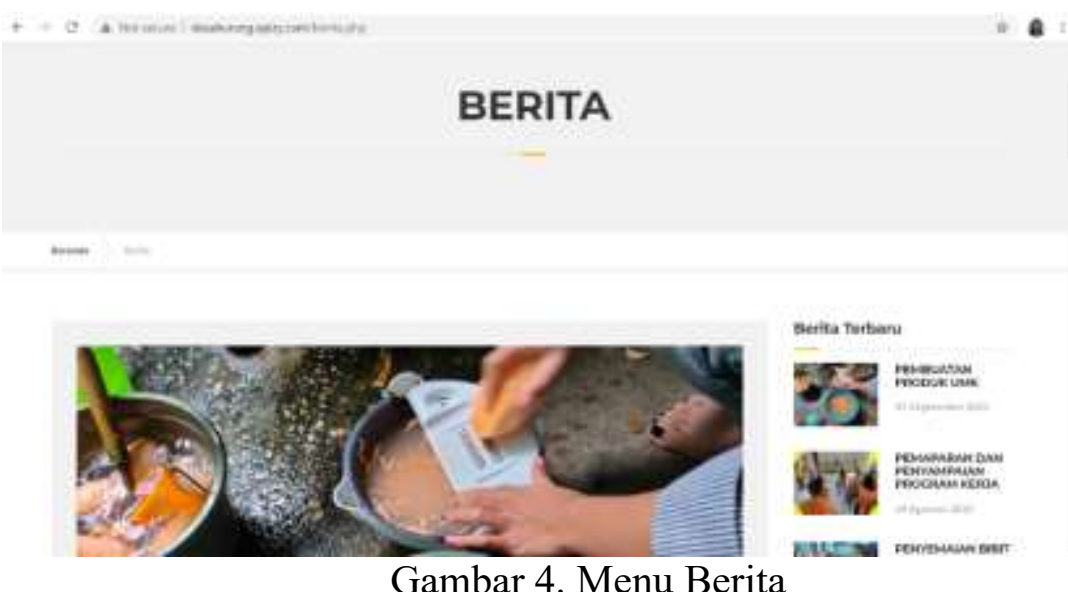

Gambar 4. Menu Berita
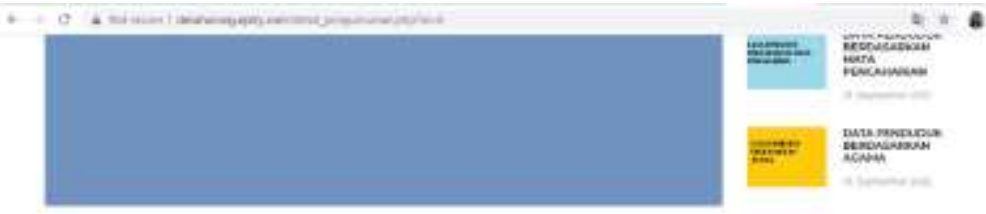

Data Penduduk Berdasarkan Usia

Gambar 5. Menu Data Desa

Menu-menu di atas merupakan menu yang ada pada halaman pengunjung. Admin dapat menambah data, mengubah data dan menghapus data serat melakukan pengaturan website pada halaman admin, dengan melakukan login terlebih dahulu dengan memilih admin pada pojok kanan atas. Setelah memasukkan nama dan password dengan benar, maka akan masuk kehalaman admin, dimana admin dapat melakukan proses tambah, ubah, dan hapus. Halaman admin ditunjukkan pada Gambar 6.

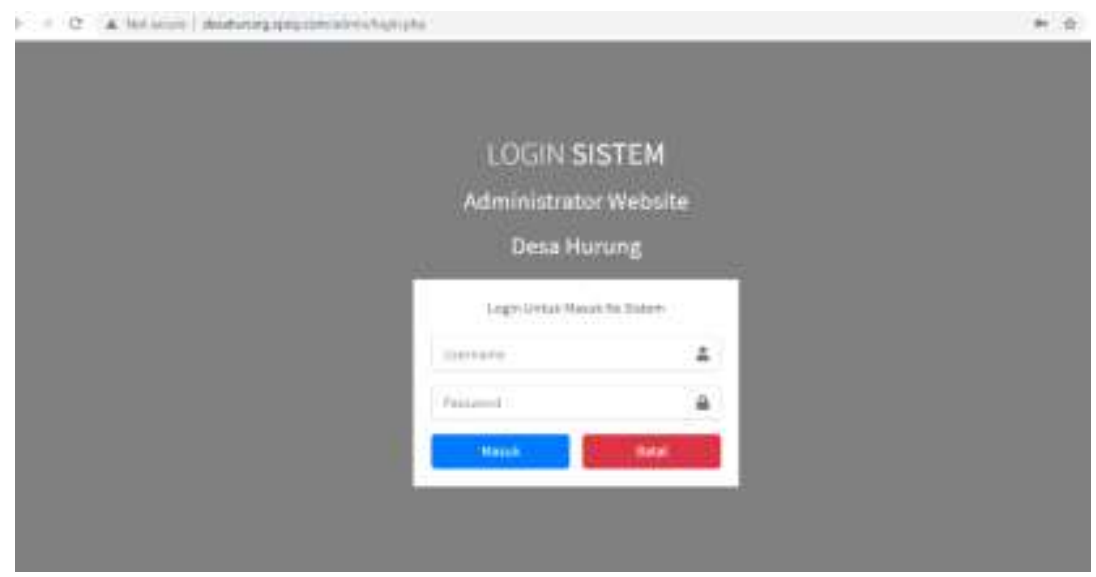

Published by:

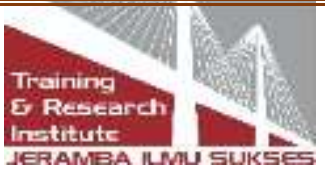




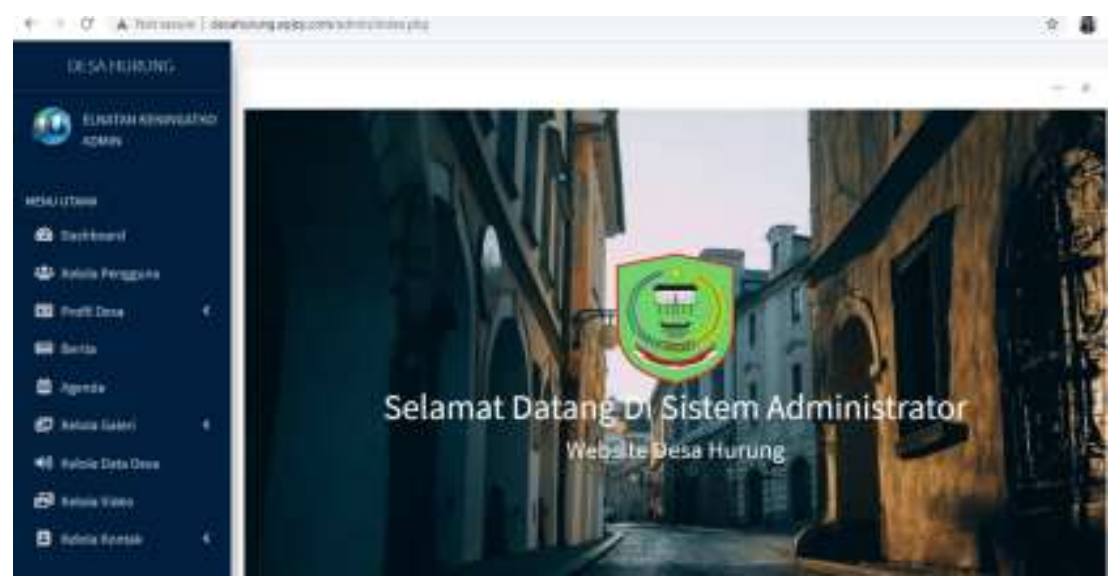

Gambar 6. Halaman Admin

\subsection{Pemaparan Materi}

Setelah Website Desa hurung selesai dibuat, tim pengabdian melakukan pemaparan materi mengenai literasi digital. Pada hari pertama kegiatan pengabdian, pemaparan materi kegiatan dilakukan secara terbatas dan bersifat nonformal kepada beberapa perangkat desa dan beberapa mahasiswa dari Universitas Palangka Raya yang saat itu sedang melaksanakan KKN di desa Hurung (ditunjukkan pada Gambar 7). Pada hari pertama, selain menyampaikan sedikit mengenai materi pengabdian, juga dilakukan koordinasi kepada aparatur desa mengenai kegiatan puncak yang akan dilaksanakan pada hari kedua.

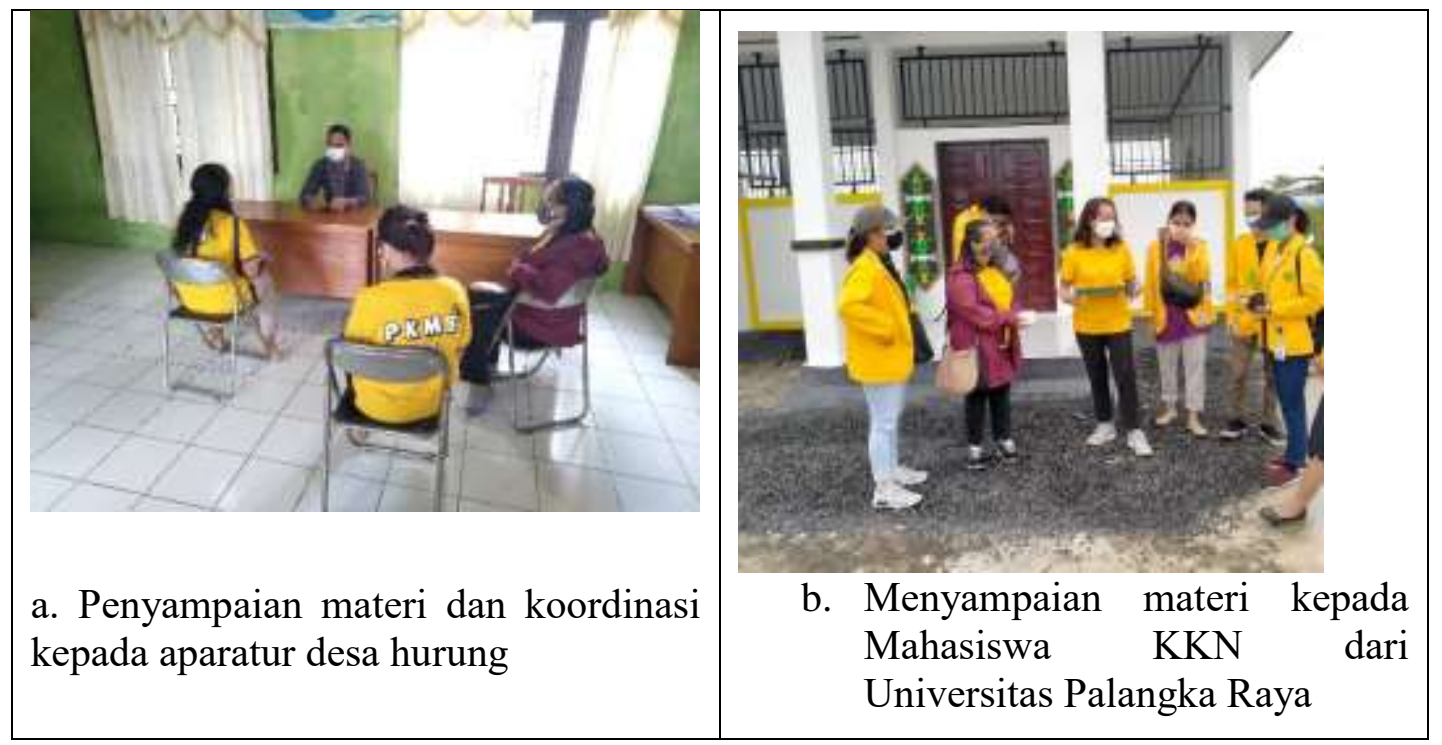

Gambar 7. Penyampaian Materi dan Koordinasi Kegiatan pengabdian

Pada hari kedua kegiatan pengabdian merupakan puncak kegiatan pengabdian. Kegiatan dilaksanakan di Aula Kantor Desa Hurung yang dihadiri oleh Kepala Desa Hurung, Aparatur

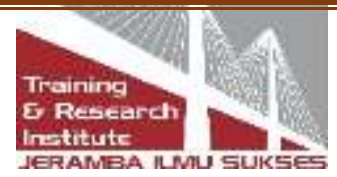


Desa Hurung, Kepala BPD, beberapa masyarakat desa, dan mahasiswa Universitas Palangka Raya yang sedang melaksanakan KKN di Desa Hurung. Kegiatan ini diawali dengan penyampaian materi Literasi Digital Bagi Warga Desa Hurung yang ditunjukkan pada Gambar 8. Kemudian dilanjutkan dengan penyampaian materi mengenai Website Desa Hurung yang ditunjukkan pada Gambar 9.

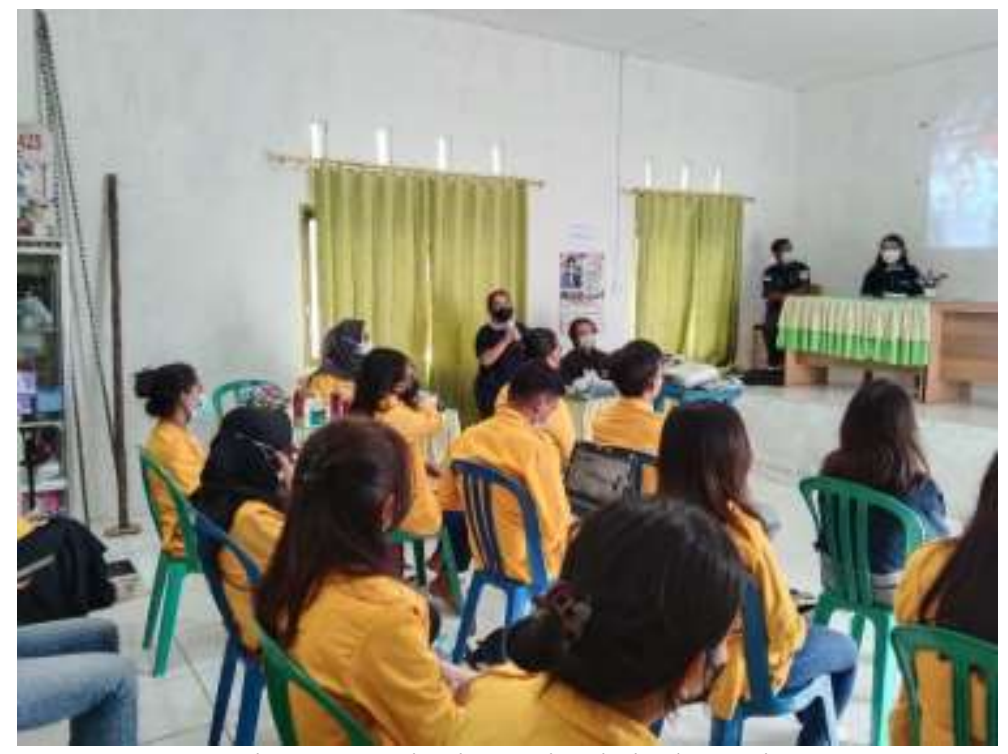

Gambar 8. penyampaian materi Literasi Digital Bagi Warga Desa Hurung

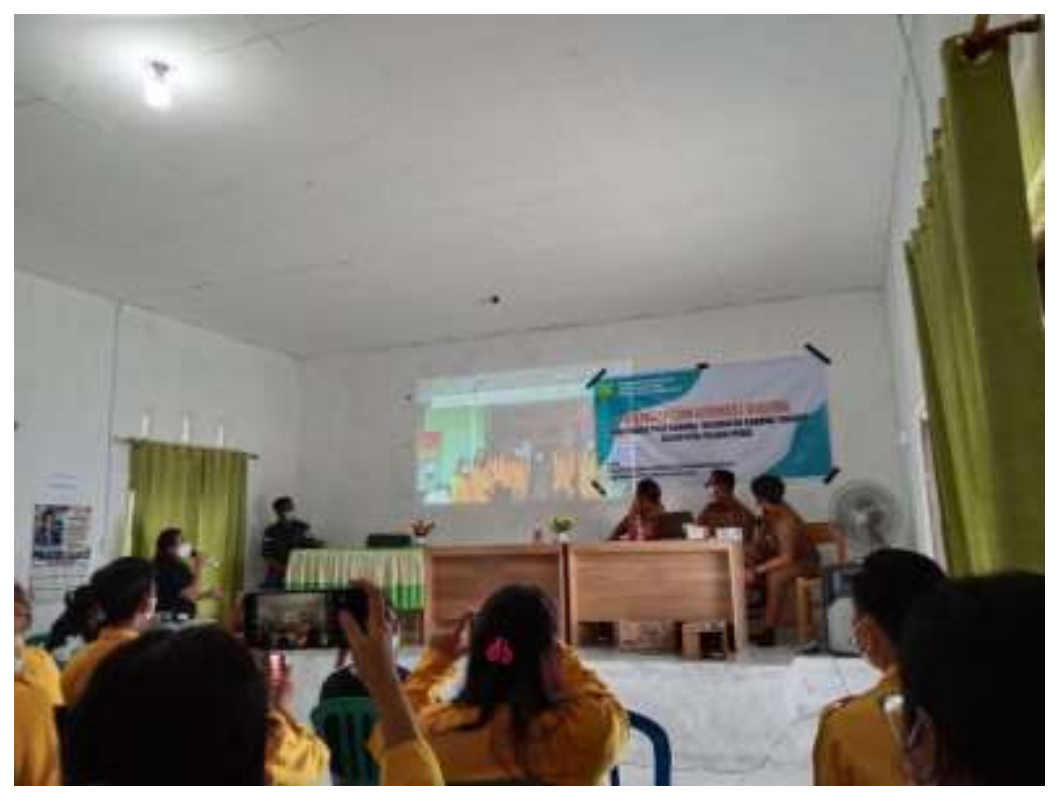

Gambar 9. Penyampaian Materi Website Desa Hurung

Kegiatan selanjutnya adalah melakukan pelatihan menggunakan Website Desa, terutama kepada aparatur desa yang akan menggunakan Website Desa sebagai admin website. Aparatur desa sangat antusias melakukan kegiatan ini karena dengan adanya Website Desa Hurung ini maka diharapkan Aparatur Desa dapat memberikan informasi-informasi mengenai Desa Hurung dengan cepat, dan dapat diakses dimanapun dan kapanpun. Diakhir kegiatan, 
dilakukan pemberian kenang-kenangan berupa plakat dan penyerahan akun administrator kepada Kepala Desa Hurung, kegiatan ini ditunjukkan pada Gambar 10.

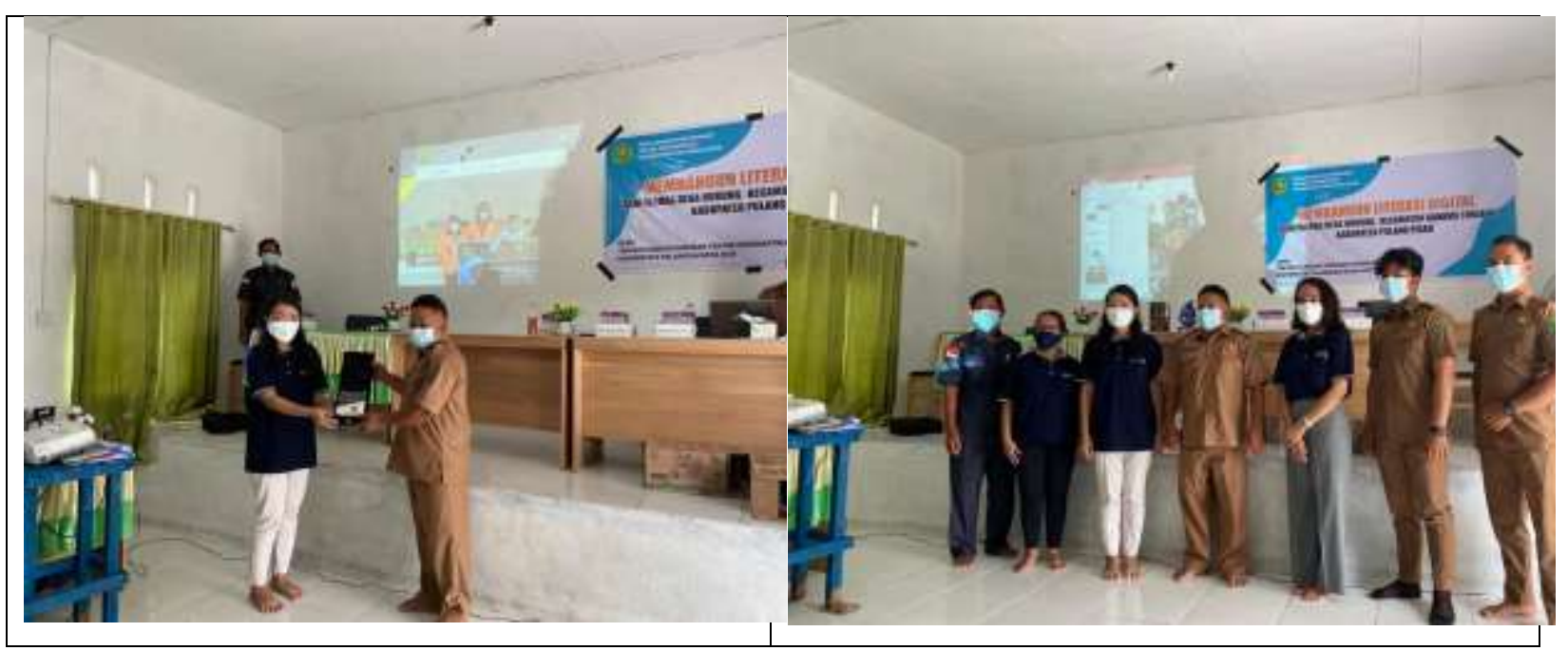

Gambar 10. pemberian kenang-kenangan berupa plakat dan penyerahan akun administrator kepada Kepala Desa Hurung

\section{Kesimpulan}

Dari kegiatan Pengabdian Kepada Masyarakat ini, dapat diambil kesimpulan :

1. Di era serba digital ini, maka perlu ada nya wawasan dan pemahaman mengenai literasi digital khususnya bagi warga Desa Hurung, sehingga Desa Hurung dapat menjadi pelopor desa yang berliterasi digital bagi desa-desa di Kecamatan Banama Tingang.

2. Dengan adanya kegiatan ini, dapat meningkatkan kemampuan warga Desa Hurung dalam menggunakan teknologi digital yaitu Website Desa Hurung sebagai bentuk dari literasi digital.

\section{Daftar Pustaka}

BPS Pulang Pisau. (2014). Proyeksi Penduduk Banama Tingang 2014. Badan Pusat Statistik Kabupaten Pulang Pisau.

Bungai, J., Perdana, I., \& Affandi, M. (2020). Implementasi literasi digital melalui pengembangan website desa sebagai upaya pemberdayaan masyarakat. Jurnal AKRAB!, $X I(1), 54-63$.

Gilster, P. (1997). Digital Literacy. New York : Wiley.

Https://www.puskomedia.id. (n.d.). https://www.puskomedia.id/blog/manfaat-dan-kegunaanwebsite-desa/. Diakses 21 September 2021.

Jimi, A. (2019). Rancang Bangun Sistem Informasi Desa Berbasis Website (Studi Kasus Desa Netpala). Jurnal Pendidikan Teknologi Informasi (JUKANTI), 2(1), 1-7. https://doi.org/10.37792/jukanti.v2i1.17 
Vol. 2, No. 2, Juli-Desember 2021

Nasrullah, R., Aditya, W., Satya, T. I., Nento, M. N., Hanifah, N., Miftahussururi, \& Akbari, Q. S. (2017). Materi Pendukung Literasi Digital. Kementerian Pendidikan Dan Kebudayaan, 43. http://gln.kemdikbud.go.id/glnsite/wp-content/uploads/2017/10/literasiDIGITAL.pdf

\section{Copyrights}

Copyright for this article is retained by the author(s), with first publication rights granted to the journal.

This is an open-access article distributed under the terms and conditions of the Creative Commons Attribution license (http://creativecommons.org/licenses/by/4.0/) 